Judit Csoba ${ }^{1}$

\title{
From a Caring State to an Investing State. Stages of a Changing Welfare Model in Labour Market Policy
}

\begin{abstract}
In this paper, we investigate the changing model of social security. The analyses are focusing on changes in labour market policies which have taken place in the countries of the European Union. With the critical review of scientific literature of welfare changes, we try to answer the next questions. What circumstances led to the shift from the welfare state focusing on welfare benefits and services to the generally accepted model of the activating? What reforms and what stages lead to the transformation of the welfare model especially in the area of labour market policies? How the earlier integration efforts, which had mainly focused on entitlement, was replaced with a market-based approach like social investment?

The most important result of the critical analysis is the presentation of the policy model transfer between the states of the European Union and the steps of the reform process, which jeopardise the enforcement of the citizen's social rights.

The first part of the study presents the theoretical framework for the transformation of the labour market policies, the key pillars of the welfare state and the term "activation state" and "investing state". The second part examines the key features of five stages of changing model.
\end{abstract}

KEYWORDS: activating state, labour market policy, social investment, social right, policy learning

RECEIVED 3 February 2021; ACCEPTED 12 February 2021.

\section{INTRODUCTION}

By the end of the twentieth century, welfare states - that had been established after World War II - were forced to introduce reforms that had an impact on the very foundations of the welfare system. The first signs of this reform process - which critics simply regard as the dismantling of the welfare state - already appeared in the second half of the seventies, but it only really started in the nineties and continues to this day. In the period of "ongoing reforms" of the welfare state by the turn of the millennium, we have created a new system of social rights. ${ }^{2}$ The earlier content and entitlements of the "third-generation rights" (Marshall, 1950) ${ }^{3}$ were "recalibrated" (Hemerijck \& Berghman, 2004). During the reform process, the model of unconditional welfare provision was replaced with a market-based approach like social investment and conditional welfare.

The present study focuses on only one aspect of this transformation process: how reform of the welfare state that fundamentally altered social rights was realised in the realm of labour market policy. We aim to investigate, what conditions and circumstances reinforced the generally accepted model of the activating and what reforms and what stages have led to the work-related welfare.

When it comes to the analysis of the welfare reform process, highlighting the changes implemented in labour market policy is justified by, among other things, the fact that recommodification and the conditional welfare model (primarily based on conditions of labour and market participation) have become widely accepted by now regardless of what kind of principles (conservative, liberal and social democratic) an analysed welfare system is based on.

\footnotetext{
1 Department of Sociology and Social Policy, University of Debrecen, Egyetem tér 1. Debrecen 4032, Hungary, E-mail: csoba.judit@arts.unideb.hu

2 Critics prefer to describe this as a restricted system or a system depriving of rights (Ferrera et al. 2000; Rueda, 2005; Palier, 2010; Butterwegge, 2014; Dörre et al 2014).

3 The first generation of right is a civil right, the second generation is the political right, and the third generation is the social right (Marshall 1950).
} 
In our analysis, we try to prove that the welfare reform process - regardless of the characteristics of welfare models - is moving in the same direction: from "decommodification" (Offe, 1984) to "recommodification" (Pierson, 2001) and from a "caring state" to an "investing state". The analysis of the interaction between labour market policy and the welfare model reform process can be truly considered a substantial field of welfare paradigm shifting research and can provide an opportunity to explore and to understand the nature of the welfare reform process, which is still an ongoing process today.

The study is based on diachronic comparative logic, change of the welfare state model over time focusing on changes in a public policy area: the employment policy. The theoretical background of the study is provided by the theory of policy learning (Hall, 1993). By conducting this study, our goal was to analyse the change of fundamental social rights and the value system of the welfare state from the 1970 s to the present day.

In the first part of the study, we explore the theoretical framework of the paradigm shift through the critical analysis of the relevant literature. In the second part of the study, we present the key stages of transformation and their main characteristics.

\section{THEORETICAL FRAMEWORK FOR THE CHANGE OF WELFARE MODEL}

In his work Social Insurance and Allied Services (1942), which was written during World War II, William Beveridge, the creator of the universal welfare model, defined the tasks of the welfare state as follows: to fight against the five "giant evils" of "Want, Disease, Ignorance, Squalor and Idleness". In his Full Employment in a Free Society (1944), written two years later, he merely highlighted one of these main goals - to ensure "freedom from idleness" - and he emphasised the necessity of creating full employment. When the welfare state was developed after World War II, the fundamental objective was to create a caring state which would seek to reduce dependence on the market (decommodification) and to distribute market incomes evenly in order to ensure the livelihoods of those concerned. Accordingly, although the welfare state was built on the idea of full employment, ${ }^{4}$ it was not in the least characteristic of it to force people to work. The access to goods was not conditional on performance or on the participation in gainful activities, but was a guaranteed right based on citizenship. Emphasis on the redistributive role of the state, independence of guaranteed subsistence from the market (decommodification) and unconditionally ensured social rights were the defining pillars of the ideal type of the welfare state (Esping-Andersen, 1990).

We investigate the transformation of the three defining pillars of the ideal type of the welfare state in the context of the theory of policy learning (Argyris, 1976; Hall, 1993). Policy learning process is "a deliberate attempt to adjust the goals or techniques of policy in response to past experience and new information" (Hall, 1993, p. 278), and policy learning theories consider the policy process over time.

Based on policy learning theories, we assume that the transposition of policy elements not only between individuals and social groups but also between political ideologies, welfare models and welfare states has been increasing over the last decades (Banks et al., 2004). According to this model, there are three levels of model adoption (Hall, 1993; Moyson et al, 2017). In the case of instrumental learning, countries only adopt individual instruments: such as linking unemployment benefits to (public) employment. The second level is the conceptual learning, where a new "theoretical framework" is created to solve the problem. We see an example of this in the mid-nineties, when each country is introducing "work instead of benefit" programmes, focusing on activation as a new concept. In practice, this concept is accompanied by a series of organisational, legislative and financial changes aimed at limiting passive benefits and expanding active labour market instruments. The third level of adoption of policy models is social learning, when not only a tool or programme system is adopted, but the whole system of values, that determines the attitude to the problem. This is how the workfare principle and practices of the USA in the mid-nineties widespread in labour market policy and become the norm in the most countries of the European Union.

In this paper, we analyse the forms and the three levels of policy learning process: the goals of the policy, the instruments that should allow to achieve these goals and the settings of these instruments in the period from the 1970s to the present day.

In the following, we present three main types of welfare state - caring state, activating state and investment state - and then we analyse the five stages of transformation in the 28 countries of the European Union.

4 "It is worth noting that full employment only applied to adult men in Beveridge's model - in accordance with the male breadwinner model - that was generally accepted at that time. It meant a 48-hour working week, 48 weeks a year, and 48 years of employment during a person's lifetime” (Hemerijck, 2013, p. 123). 


\section{The "caring state"}

When defining the notion of the welfare state, Esping-Andersen did not only focus on the guarantee of social rights but also regulated the relationships between the individual (and the family), the state and the market at the same time. In this context, he clearly defined the responsibility of the state in securing the basic welfare of its citizens and in ensuring that their basic needs (education, health, security and economic well-being) that are not satisfied by the market are met.

Thus, the ideal type of the welfare state, as a "caring state", is based on the following pillars:

a) To guarantee social rights while emphasising decommodification, that is, freedom from the obligation of work

b) To manage social inequalities caused by the market through social welfare redistribution, that is, to make it possible for those who are excluded temporarily or permanently from the labour market to enjoy financial security

c) To regulate the different roles of the state, the market and the individual (the family) in the reproduction of welfare. This means that the role and responsibility of the state is emphasised in guaranteeing the well-being of citizens, in creating a balance between economic interests and social interests, in making sure that they are motivated and interested, and, above all, in securing their individual rights (Esping-Andersen, 1990).

With regard to employment, the welfare states of the European Union were characterised by high employment rates and a system of labour market institutions that ensured a high degree of security for the labour force until the second half of the seventies. These included extensive social security systems that were mostly operating on a mandatory basis, granting a high level of income replacement. A further specific feature of the caring state was the protection against dismissal, support for passive and active labour market policies and the active involvement of the state in the regulation, financing and implementation of welfare/labour market programmes.

\section{The "activating state"}

However, the "caring state" has been facing progressive economic and social challenges since the 1970s. The process of economic transformation defined by globalisation has been accompanied by social and ideological changes, which, by the mid-nineties, transformed the framework conditions for the functioning of national governments and welfare states. One of the main features of the transformation was the gradually decreasing social solidarity and the redefinition of the role of the welfare state. Instead of a "caring state" that guarantees social rights, the image of an "activating state" that expects/enforces economic and social activity and "self-care" has become increasingly accepted in politics and public thinking.

Defining the term "activating state" is quite a challenging task, as the phrase has several different meanings. ${ }^{5}$ On the one hand, it means a kind of behaviour that deems active participation in community activities natural, and that hence fulfils the need for increasing inclusion. On the other hand, the term "activating state" has recently gained a negative connotation, which highlights the conditionally provided welfare care by the state and the obligatory nature of work in the system. In many cases, it also refers to the fact that these obligations are always present, even if the possibilities of acting and actively participating are not guaranteed.

Some authors (Pierson, 1998; Sonnenfeld, 2001; Butterwegge, 2015) doubt that there is an approach to the "activating state" that is in any way neutral, and they claim that activation is exclusively about the disciplining of those being affected, while the necessary solidarity with them is missing. According to these authors, activation is essentially a euphemism for repression, which makes compulsory work presentable again. Others (Lodemel \& Trickey, 2000; Trube, 2003; Rueda, 2007) doubt the prospects of the "activating state" since they believe that the social model of the activating state could prove to be unsuccessful in times of massive and structural unemployment.

\footnotetext{
5 In the different ideological models, various terms have become accepted to describe more or less identical phenomena: the "enabling state" and the "workfare state" in the USA, the "work first" model in the UK, the "activating state" in Germany, etc. (Gilbert \& Gilbert, 1989; Torfing, 1999; Dingeldey, 2011). This paper aims to define the term "activation" and lay down the general terminological framework of the activating state, and it is not intended to make a comparative analysis of different terms used in different countries.
} 
Despite of all the social and professional debates highlighting the risks of activation, the direction of welfare reforms has been heading towards the activating state in Europe following the second half of the 1990s, and in most countries, welfare conditional on work has superseded one of the fundamental elements of the Esping-Andersen welfare model: the provision of social security that is independent from the market. Following the millennium, "recommodification" has replaced "decommodification" as the keyword of European welfare models.

\section{The "investing state"}

The ideological foundations of the "investing state" model can be found in the work of Giddens (1998), who initiated the revamp of the social democratic welfare model in second half of the nineties by developing the model of the "social investment state". The objective of "third way" reforms designated to transform the welfare model is to replace the previous welfare state that mainly provides passive support with one that is built upon the activity and participation of citizens and that regards welfare expenditure as an investment rather than compensation. According to Giddens, the support of the welfare state is an investment that pays off due to the activity of participants, as over time, employment rates will increase, citizens' self-sufficiency will improve and the level welfare dependency will be reduced. Thus, education and service systems need to be established that are able to specifically remedy the disadvantages of peripheral social groups - those with low levels of education, single mothers, individuals of disadvantaged regions, etc. - and enable labour market participation. The idea of an "investing state" presumes a strong state and extensive participation on the state's part, while the civil sector also plays a substantial role in such state. At the same time, the relation between the state and the society is also changed. The state - in order to improve its citizens' skills and employability - starts to continuously invest, especially in education and training, but calls for the active and proactive participation of concerned citizens. As opposed to the previous social democratic model, where citizen and social rights prevailed, this model offers "no rights without responsibilities". For this reason, it is advised to reduce the time frame and substitutive nature of passive benefits and to use active labour market policies extensively.

Advocates of the "social investment" model (Palier, 2010; Morel et al, 2012; Hemerijck, 2017) that gained attention most recently following the millennium follow the traditions established by Giddens', but they also believe that his "social investment state" model leaves many questions unanswered, which have to be clearly answered when constructing the welfare model of the twentyfirst century. One of the components of Giddens' model that is often questioned by them is that his model is based on selective discretionary benefits that call for individual activities and opportunities instead of entitlements, and the state functions as a social investor, referring to people as "human capital". The strictly analysed productive social policy - which primarily focuses on economic interests and profit - necessarily splits the target group and only supports those who can generate profit with little investment.

The advocates of the new model assert that "social investment" - contrary to the third way model - serves the purpose of augmenting social benefits, but does not aim to replace them. They also believe that social protection ensuring existence is the prerequisite to successful social investments (Esping-Andersen, 2002; Ferrera, 2009; Hemerijck, 2015).

The "social investment" model - as we can see - is in fact not the renaissance of the Scandinavian model or the "caring state" model. Benefits are not universal, the groups targeted by the labour market policy are mainly those peripheral groups of the labour market that can be most quickly activated, and the model does not offer a clear-cut answer as to what would happen to multiply disadvantaged groups who have lost their work capacity. The "social investment" model does not accept the idea of decommodification. Moreover, the advocates of the "social investment" model believe that proper social participation can only be achieved if (labour) market participation is fulfilled as well - i.e. avoiding welfare dependency and relying on individuals' own achievements instead - and it does not universally guarantee the social rights identified as "third-generation rights" by Marshall (1950).

To sum up the theoretical framework of the paradigm shift of the welfare state, the most significant characteristic is the regulation of the conditions of the redistributive income that reduces the losses caused by the market. In contrast to the "caring state" welfare model that is independent from the market, and that utilises the concept of universal access, the idea of conditional welfare benefits - that are mainly conditional on work - emerged, also being referred to as "recommodification", bringing back the citizens to work and giving a new interpretation of social rights. The small steps in the process of change obscure the most important element: the fundamental transformation of the model and the marginalisation of social rights. 


\section{METHODOLOGY}

Our analysis has been organised in this study around one main questions: we want to know, if the introduction of activation although there have been different rates, levels and services in the welfare states of the European Union over the past decades - is moving in the same direction: from "decommodification" to "recommodification" and from a "caring state" to an "investing state"? This paradigm shift in labour market policy we will describe as a model of policy learning, which takes place over decades of continuous transformation, started in tiny steps with instrumental learning (individual instruments), and then continues with the new individual instruments spread unnoticed and became a conceptual learning crated a new theoretical framework, and finally expands as a new form of social learning that determines the attitude to the whole social security system (Hall 1993).

Longitudinal policy learning research raises challenges in terms of research designs. There is a lack of tools in the literature for measuring policy change (measure/type), and measuring learning processes in policies is also difficult due to the limited objectivity (Zito \& Schout, 2009). Considering the limitations, we also chose the critical review of relevant scientific literature as the data source and methodology of the analysis.

The time frame of our analysis ranges from the seventies to the present. We analysed the transformation of the welfare state in European Union from a labour market policy perspective into five stages. The sectional boundaries are linked to significant changes in the economic, social, political and environmental factors affecting the welfare system. Accordingly, the following section boundaries and the most important features of the section are outlined:

1. The illusion of the temporary crisis and the "caring state" (mid-'70s to the late-' $80 \mathrm{~s}$ )

2. The phase of cost reductions and austerity: the crisis of the "caring state", beginning of activation (1990-1995)

3. The "third way" experiment: balancing between social and market interest (1996-1999)

4. Changes after the turn of the millennium: the transition from active to activating labour market policies (2000-2008)

5. Reform process following the 2008 global economic crisis: the emergence of an "investing state" (from 2009 to until now)

Reviewing each era, we follow the next four analytical aspects:

- A brief analysis of the environmental changes that trigger the economic and social changes that characterise the stage (environmental conditions)

- Outlining the most important welfare reforms and their value and ideological changes (general changes in the welfare model)

- Introducing the most characteristic changes in labour market policy (specific changes in the public policy)

- Presenting some of the consequences of the changes (the impact of changes on the welfare model)

In analysing the different phases of rebuilding of the welfare system, special attention is paid for the transformation of the three pillars that identify the welfare model (decommodification, state-guaranteed welfare redistribution and balance between economic and social interest) and the three "orders" of policy change (instrumental learning, conceptual learning and social learning) (Hall 1993).

\section{THE PHASES OF THE REBUILDING OF THE WELFARE SYSTEM}

\section{The illusion of temporary crisis and the "caring state" (mid-'70s to the late-' 80 s)}

This period follows directly after the era when the welfare states were at their heights. The preceding period had lasted from the 1960 s to the early 1970s, during which the European countries had established active policies in reaction to insufficient labour supply, in order to ensure that well-trained workers were available to the rapidly developing industrial sectors. Thanks to the labour shortages that were the result of the dynamically developing economy, western capitalism did not develop a sizable and visible "reserve army" (Lutz, 1984, p.186), and unemployment and poverty were not widespread. However, there were many problems with the "marginalised groups" of society (Geissler, 2006, p. 201), the lowest 5\% of the population.

The changes started after the 1973 and 1979 oil crises. The accelerating inflation and unexpectedly sharp rise in unemployment, as well as the appearance of long-term unemployment, were a shock to the economy, but the states continued to search for solutions in the framework of Keynesian economic policy. For a long time, it was believed that this was just a cyclical phenomenon, and the problem could be contained through an appropriate countercyclical intervention by the welfare states. Under these circumstances, 
most countries set the objective of "maintaining" the unemployed, so that the workforce would be able to enter into employment immediately on the primary labour market after the crisis had passed (Bonoli, 2005). To this end, and in order to stabilise purchasing power, they applied the Keynesian policy of stimulating demand. The main aim of state intervention at both the macro- and the microeconomic levels was to avoid debt crises. Changes in the economy - the decline of mining and heavy industry, and the emergence of the tertiary sector - mainly had a negative impact on men. In order to ensure the livelihood of families, unemployment benefits were introduced, and the unemployment insurance system was established in almost all countries. Since the crisis was considered to be temporary and the maintenance of purchasing power believed crucial to the operation of the economy, the evolving unemployment insurance and passive systems were rather generous, especially in countries with a conservative welfare model. The development of a high level of benefits, and especially of unemployment benefit, was also due to the fact that the trade unions - which were still strong and well-organised actors at this time - defended the positions of welfare strongly. Family support systems were strengthened, and access to services funded by the EU Structural Funds was facilitated.

With the introduction of these benefits, however, a gradual shift started from social rights acquired by contributions towards needsbased benefits financed by taxes. It was typical that in order to reduce unemployment and excess supply in the labour market, groups of inefficient workers were excluded from the job seekers. Those without professional qualifications, women, people with disabilities, young people without work experience and older people facing retirement were compensated and kept away from the labour market. Decommodification and the state-guaranteed social right were a general feature of the first period. In the short term, this method indeed seemed like a favourable solution, since it reduced unemployment and ensured purchasing power for the economy through passive income. However, there was a high price to pay, and long-term inactivity led to the development of welfare states that were expensive to maintain and in many cases unsustainable in financial terms (Gilbert \& Gilbert, 1989; Pierson, 1998; Bonoli, 2005).

By the end of the first phase, the welfare state optimism of the seventies was disappearing. The ability of the welfare state to function was questioned. After experiencing the ineffectiveness of counter-cyclical state intervention attempts on Keynesian-based economic policies, decision makers turned to new solutions at the end of the period. The possibility of transforming generous unemployment insurance and passive welfare systems has been analysed and the first reforms were introduced. ${ }^{6}$ The first signs of instrumental "order" of policy learning had already emerged. One of the elements of the emerging savings programme was the reduction of the duration of unemployment benefits and the amount of income replacement. However, the process of widening the reform process took place only in the next cycle.

\section{The period of cost cuts and austerity: the crisis of the "caring state", the beginning of activation (1990-1995)}

At the beginning of the 1990s, it became clear that it would not be feasible to channel the economic and social changes through the reform programmes that had begun in the late eighties. ${ }^{7}$ The number of unemployed was rising constantly. In 1993 , the unemployment rate in Europe had crossed the psychological threshold of 10\% (EC, 1993).

As a result, the era has become a period of budget stabilisation and cutting of public expenditure. Neoliberal ideas received much more support than in the previous phase, and the economic stability and the primacy of market interests became dominant. The view that there is no welfare state without a stable economy became widely accepted. The welfare state itself was subjected to a serious of attacks by members of the new neoliberal school that proclaimed Hayek's (1991) principles: increasing government intervention could easily lead to welfare addiction and a totalitarian government. By the end of the decade, neoliberalism and the theory of the "negative state" had become widely accepted.

The European Commission's White Paper entitled "Growth, employment and competitiveness" (1993) also reflected the strengthening of economic interests, and the OECD Job Study (1994) also had a significant impact on the development of the welfare reforms. It was one of the prominent messages of the strategies that strong social protection would raise the cost of labour above market prices, and high wages, high taxes and the strong bargaining power of trade unions would hamper economic growth

6 See e.g. the gradual extension of the retirement age, the expansion of active labour market tools among Western European countries or the emphasis on the role of public employment in conservative welfare states (especially in West Germany) in the late 1980s.

7 Despite the changes, some countries still retain the labour market relief programmes that they had used previously, such as early retirement. These include, for example, Austria. 
and competitiveness considerably. The strategies were predicted to launch a strong deregulatory programme, maintain low minimum wages, reduce wage costs and taxes and reform the system of unemployment benefits (Rueda, 2007).

Despite the economic and cultural differences between European countries, the changes in the area of labour market policy showed many similarities. In all countries, ensuring labour market flexibility and the activation of inactive social groups became the central theme (Giesecke, 2006). ${ }^{8}$ As a result of the reduction of the duration of unemployment benefits and the restriction of the range of insurance-based benefits, an increasing number of social groups appeared that were no longer protected by a welfare net operating via insurance systems. In addition to insurance-based benefits, there appeared a growing number of conditional, meanstested benefits. The selective discretionary granting of these benefits and the low level of income replacement weakened social security and undermined the social rights.

In 1993, the German Parliament adopted the "Savings, consolidation and growth" programme9 presented by the CDU/CSU/ FDP coalition, which contained a number of austerity measures. The essence of the restriction was the transfer benefits and the active labour market programmes that have been developing since 1989/1990. The result is a shift from the insurance-based and rightsbased welfare state towards a means-tested model. The reciprocal nature of the benefits and the range of sanctions also increased. In 1994, three hundred thousand unemployed were obliged to work in public employment in order to get their benefits. In Denmark, with the adoption of the reformed Employment Act in 1994, the age of activation had also begun. In parallel with the slow reduction of the duration of unemployment benefit, job rotation and training programmes were established, and the range of supported employment opportunities also expanded (Schmid \& Oschmiansky, 2006; Dingeldey, 2011).

In the second phase of the welfare state - because of the dominant ideology, that in times of accelerating globalisation, competitiveness can only be ensured by reducing social security and downsizing the welfare system - welfare benefits provided on an insurance basis decreased, while the range of recipients of means-tested social benefits is widening. Frequent review of benefits or substitution by lower-level support has become a feature of the era, but active labour market incentives have also been steadily gaining ground (Bonoli, 2011). In the second period of the welfare transformation, the representatives of different welfare states were no longer just some instrumental elements borrow from each other, but the whole system. On the new level of the policy learning, conceptual "order" created a new "theoretical framework" to solve the problem. The "work instead of benefit" programmes were accompanied by a series of organisational, legislative and financial changes and aimed the limitation of social right of the citizens. Instead of decommodification, the "work-based" welfare model has been strengthened (conditional transfers) and the active labour market instruments have been expanded.

However, the stabilisation process initiated by neoliberal economic philosophy did not bring the desired results either in labour market policy or in stabilising public finances. This led to the strengthening of the positions of social democratic parties and leftist political forces by the mid-nineties, who began to develop a new - or emerging - economic and welfare model.

\section{The "third way" experiment: balancing between social and market interests (1996-1999)}

In contrast to the neoliberal trend which had dominated the political palette of the early nineties, social democratic and left-wing political forces gained leading positions in the middle and the second half of the decade. The left, represented by Tony Blair (19972007), Gerhard Schröder (1998-2005), Wim Kok (1994-2002), Poul Nyrup Rasmussen (1993-2001) and Lionel Jospin (19972002), was left with much less leeway when it came to managing the economic problems that arose in the second half of the nineties than the politicians of the "golden age of social democracy" (1945-1973). Their ambition to reform social democracy and to develop a new economic and welfare model became manifest in the "third way" experiment, the attempt to reconcile market and social interests. In this context, globalisation was interpreted as a resource and welfare expenditure as social investment. The new "left-wing realists" conducted a policy of welfare rationalisation that often surpassed even the policies of the liberal parties. These efforts are often

8 Critics have been disputing since the appearance of the new model that dismantling workers' rights and security would be a long-term solution for treating the symptoms of the crisis. The general spread of flexible forms of employment exacerbates social inequality, reduces purchasing power, erodes the carrier prospects of those concerned and has a negative impact on the income level of those who work in non-flexible forms of employment as well (Bothfeld et al, 2009; Butterwegge 2015).

9 Erstes Gesetz zur Umsetzung des Spar-, Konsolidierungs- und Wachstumsprogramms (1. SKWPG und 2. SKWPG) 
levelled with the criticism that the dividing line between neoliberal doctrines and reformist social democratic programmes is very thin (Giesecke, 2006; Rueda, 2007; Palier, 2010).

The leeway of left-wing political forces in the second half of the decade was also influenced by international developments which were controlled by the relevant international organisations. In this regard, the EU was of utmost importance, whose role was characterised by a dichotomy during this period. On the one hand, due to the dominant political trends, the EU was open to the "third way" experiments that tried to reconcile social protection with economic growth. In this context, the area of social policy was a productive factor that was indispensable for economic development. As a result of this, and as the culmination of the Luxembourg process, new articles appeared in the Amsterdam Treaty of 1997 (Articles 125-130) in the focus of these was the principle of open coordination. ${ }^{10}$

In parallel to all this, the EU created the EMU (Economic and Monetary Union 1992), which specified rigorous conditions for the member states in order to achieve a stable common currency, and in this regard, it clearly represented strong neoliberal economic policy views. It was also along this approach that the "deregulation process" launched during the previous stage was carried on, limiting the role of the welfare state. In most countries, tools and resources were assigned to municipal governments, and a new labour law was legitimised which particularly supported flexible forms of employment.

These atypical forms of employment culminated in the concept of "flexicurity" as a key element of the EU Employment Strategy in the new millennium. The most influential theorist of the activation policy of this period, Giddens (1998), adopted this philosophy of activation from the Danish model and made it one of the central ideological elements of "third way" policy.

Trade unions tried to achieve greater social expenditure ratios during the budget negotiations, while promising that they would not enforce wage demands that are unacceptable to the market. It is seen as one result of the tripartite system that the social partners have agreed to make the labour market more flexible as well. Critics regard this as a complete failure of the trade unions, since in this way they have legitimised through these negotiations the workers' deprivation of rights when flexible forms of employment were introduced (Butterwegge, 2015).

The new content of the conceptual learning "order" in the third period of the welfare transformation - "no rights without obligations" - became one of the defining "theoretical frameworks" of welfare states at the turn of the millennium. This gave fresh impetus to activation policies.

However, the changes observed in the third cycle, despite the fact that the political background was favourable, did not strengthen the welfare state in every aspect. This era, summarising intentions and implemented programmes, can be characterised as an intensive phase of reducing welfare benefits and as an age of institutional reform. Critics of the "Third Way" model - due to the decrease in passive benefits and the continued exclusion of social rights - were very small between the neoliberal doctrines and the reform social democratic programmes. Although the statements of left-wing political forces proclaimed the strengthening of the welfare state, the welfare reforms implemented did not reflect these intentions.

Around the turn of the millennium, following the loss of the left-wing parties, a straight path led to the completion of activating labour market policies.

\section{Changes after the turn of the millennium: the transition from active to activating labour market policies (2000-2008)}

The fourth phase of the reform process was a period of ground-breaking changes and pioneering reforms. The model of the activating state became dominant not only in liberal and conservative welfare regimes but also in the Scandinavian welfare states too (Knotz, 2018). The nature of the problems the policy should deal with, the goals of the policy, the instruments that should allow to achieve these goals and the settings of these instruments social learning shown new "order" of policy learning: the social learning. The policy paradigm, the whole system of values, that determines the attitude to the problem has changed, and the three pillars of the welfare model were endangered.

Society's attitude towards welfare recipients had changed fundamentally. When granting welfare benefits for the unemployed, it was not acquired rights that played a decisive role, but worthiness. They were no longer seen as victims of changes in the economic

10 In the two key documents of the OECD in this period (Job Strategy of 1997 and The New Social Policy Agenda of 1997), the economic and social areas also were given equal weight and importance, as two interdependent areas. 
system and subjects of welfare compensation, nor as targets of social investments - as the theorist of "third way" policy, Giddens (1998) referred to them - but as "expenditure items" that hindered economic development and represented a burden for the welfare system.

The reform package has been well suited to the debate on self-care and the need for individual responsibility in many countries in Europe at that time (Giddens, 2001; Offe, 2003; Knuth, 2005; Wiesenthal, 2006). Most of the "out of work" social support changed into "in work" support, and the definitions of working capacity and "suitable work" were fundamentally transformed as well. They had to rely on individual performance instead of community protection, and the solidarity-based insurance systems drifted towards equivalence-based or selective discretionary benefits.

It was a defining feature of labour market policy changes after the turn of the millennium that comprehensive reform programmes were introduced which had an impact on the fundamental principles and practices of earlier labour market policy. The first in the row was the United Kingdom, even before the turn of the millennium, which introduced the New Deal programme in 1998, and was joined by Germany, with the adoption of the Hartz reforms in 2003/2004. The Netherlands also continued this process as it announced the Work and Welfare Act (WWB) also in 2004, as did Denmark with the "More people into employment" programme adopted in 2002. The common feature of the reform programmes was the "recommodification", the linking of welfare benefits to more intensive work and the "social obligations" - mainly the obligation to participate in the production of community goods instead of social rights.

Another significant area of change was the transformation of the institutional system, ${ }^{11}$ through which the social and unemployment benefits were merged, and welfare benefits were reduced to ever lower levels. The expression by which people of active age who receive benefits are being referred to has also changed: they are not called unemployed or social aid recipients any more, but job seekers. The term is also meant to serve as a means to reshape the passive attitude into an active one and to indicate that support is conditional on the individual's initiative to change his or her labour market status. Most of the former socialist countries also adapted these models and shaped their welfare reform programmes accordingly (Bonoli, 2005; Bonoli \& Palier, 2007).

In the first years after the turn of the millennium, the fundamental aim of the reform of the welfare system and the reform of the employment policy was to reduce the number of unemployed and inactive people and to decrease the public expenditure related to the target group. Another important goal was to alleviate the much-criticised welfare dependency and to improve the self-sustaining ability of the target group. In contrast to the "means-test", the "work-test" was used in the examined cycle, which focused not on social rights but on compulsory activity and individual responsibility. In the case of welfare benefits, the "accounting approach" prevailed: only "investments" (providing welfare and services) were initiated, if they could benefit from it (in return for the benefit, they waited for return) (Butterwegge, 2007). The "workfare" character of the welfare model has strengthened. All actors in society have been identified as economic actors and not citizens, and citizens have lost a lot of their citizenship status and rights.

The undesirable consequences of the "activating state" model were already evident before the 2008 economic crisis. Workfarelike labour market policy generates low income among the employed, deprives citizens of their social rights, and returns them to dependency on poorly paid jobs. It is divisive in political and social terms, weakening democracy, social capital and the possibility of inclusion. With the intensification of the dysfunctions of the "activating state", the need for a new welfare model has been increasingly evidenced by the outbreak of the 2008 global economic crisis.

\section{Reform process following the 2008 global economic crisis: the emergence of an "investing state" (from 2009 to until now)}

As a result of the 2008 global economic and financial crisis, the welfare reform process -started at the turn of the millennium continued. EU governments have been constantly looking for ways to develop a model of a sustainable welfare state with adequate social protection in changed circumstances. Over the course of the reforms, the fundamental objectives - ensuring the balance of the national budget, increasing the responsibility of the citizens in ensuring their own existence, reducing the welfare dependence and

11 As part of this process, so-called Job Centres were set up, which jointly dealt with clients who had formerly received unemployment and social assistance benefits (e.g. Job Centre Plus in the UK, 2002, Job Centres in Germany, 2003, and Denmark, 2007). 
increasing individual participation in the labour market - had not changed fundamentally until the end of the decade. However, it has become more evident that an approach that focuses solely on economic interests has serious economic and social risks (e.g. declining market demand, increasing poverty and social inequality, democratic deficit and radicalisation). Expert assumptions that have emphasised the need for an enhanced role of the welfare state since the turn of the millennium and the timeliness of a new welfare model have intensified. Contrary to the concept of the "third way" model as defined by Giddens (1998), social spending was not interpreted as a replacement for "social protection" or "social promotion", but was considered to be a social investment, as a new area of action for the welfare state. Earlier criticism of the functioning of the welfare state and expert proposals for renewal the European welfare model (Ferrera et al, 2000; Esping-Andersen et al, 2002; Hemerijck \& Berghman, 2004; Bonoli 2005; Morel et al, 2012) had an impact on EU welfare strategies. The change has been urged by the new types of welfare and economic risks that have intensified in the meantime (ageing society, increasing proportion of working poor, emerging labour shortages, intensifying migration processes and integration conflicts).

The "recalibration" of social policies for the consolidation of welfare states was launched by the Social Investment Package (EC, 2013), adopted by the European Commission in 2013 for the 2014-2020 planning cycle. The aim of the renewable strategy was to modernise the welfare systems of the Member States and to improve citizens' resilience to social risks. In contrast to the decreasing role of the state in social security in previous years, the welfare state appeared in a new role, becoming an "investing state". The "re-calibration" of the welfare state was intended to be achieved through social investment. Although the new "investing state" model continues to activate, widen the employment of citizens, it does, however, focus more on prevention, opportunities and skill development, and training; guarantees minimum wages; reduces social and income inequality; and contributes to the quality of life of citizens. Three key target groups of the strategies are the children, the youth and the women. The changing strategy is a good reflection of the current economic and social situation and new risks of the twenty-first century (Morel et al, 2012; Nolan, 2013; Hemerijck, 2013; Hemerijck, 2015).

As a result of this process, it has been introduced in some European countries, for example, the state-funded institutional system of day care for children (e.g. providing compulsory preschool spaces: Germany 2013, Hungary 2015), the Youth Guarantee Programme 2014 for young people in the EU Member States, and series of further programmes to support women's participation in the labour market.

In the post-millennium period in the mainstream labour market policy, the expectation of self-sustainability has become a priority, and in the job-creation, growth and investment-centred strategy, the primacy of market investors has become crucial instead of social right or quality of life. This is basically due to two factors: In most EU countries, the resistance of those who represent the social interests of marginalised groups in the labour market and emphasise the welfare functions of the welfare state (e.g. trade unions) has been significantly weakened after the turn of the millennium, while the positions of deregulation parties representing economic interests have strengthened (Mailand \& Arnholtz, 2015). With the emergence of flexible forms of employment, low incomes have led to relatively low success rates, high levels of job turnover, not just economic crisis cycles but also new forms of employment. Workers moved in and out of these jobs, increased the proportion of those with precarious status, new social problems (precarious employment, "working poor", erosion of skills, insufficient social security, etc.) (Bonoli, 2011; Card et al, 2017). "Social investment" is the development of people's abilities and the promotion of their social and labour market participation which is not only about individual welfare but also economic interests in order to ensure the EU's economic competitiveness. The responsibility of the welfare state in managing new social risks is strengthened, even if only for certain target groups: children, women and young people. The new ecosystem has changed after the Great Depression of 2008 could be the starting points for a new model of social learning that strengthens social rights, creates a new partnership between the state and the citizen and can contribute to the creation of a new model of the welfare state. At the same time, the "investing state" model is no longer counting the "decommodification" principle, one of the decisive elements of welfare states that emerged after World War II. It is much more attached to the market, performance-oriented and productivity-focused. The principle of distribution versus social right-based universality is the selective discretion, which also entails the risk of further exclusion of less productive social groups (Cantillon, 2011; Bengtsson, et al, 2017).

The theoretical discussions about the characteristics and operation of the "social investment" model have not yet been completed (Hemerijck, 2015; Hemerijck, 2017). In most cases, there is still a lack of clarity of the novelty, theoretical framework and peculiarities of the model, as well as a series of empirical macro data to justify efficient operation. 


\section{CONCLUSION}

After the seventies, the fundamentals of the welfare state as a result of changing economic, ideological and social environmental conditions are gradually being questioned. Providing the goods and services and to create social security for citizens, to fulfil its original function is no longer able without reforming its institutional system and the basic social rights. Summing up the reform processes that have taken place from the seventies to the present, fundamentally transforming the assets and institutions of the welfare states, we cannot clearly justify that the state's involvement in the five periods we examined was a gradual and continuous decline. This finding would be particularly inadequate in the areas of work and employment, where we are faced with increasing state involvement, including continuous control, in stimulating employment or activating formerly passive care.

Examining the changing character of a welfare state in the last decades made it clear that is not the most important issue, if there are fewer or more "states responsibility" in the ever-changing welfare model. The most important question is during the reform process what kind of consensus is creating the "caring"/"activating"/ "investing" state between the interests of the economy and society to guarantee the elementary well-being, social security and social right of - all, and not just high-productivity - citizens.

In our study, we followed the changes in the three pillars of the welfare paradigm and the levels of policy learning theory. Due to the size limitations of the study, we only had the opportunity to analyse the most important features of the transforming welfare paradigm, focusing on the changes that have taken place in the field of labour market policy. In the context of the short analysis, we did not have the opportunity to explore and comparatively analyse the unique characteristics, specific purpose, and toolkit of different welfare models (Esping-Andersen 1990), and also many unknown factors remain about the mechanisms of policy learning process and its effect on policy change.

We think that in future stages of the research based on new and refined concepts and theories, it will be possible to analyse further distinctions between "orders" of change (Hall 1993), role of ideas (ideational scholarship Blyth 2011) and political action (Blyth 2011; Carstensen 2011), and also to explore the essential elements of paradigm shift in the welfare transformation.

\section{ACKNOWLEDGEMENTS}

This study was prepared with the support of EFOP 3.6.3-VEKOP-16-2017-00007 - "Young researchers for talent" - Supporting career in research activities in higher education project.

\section{REFERENCES}

Argyris, Ch. (1976). Single-Loop and Double-Loop Models is research on Decision making. Administrative Science Quarterly, 21(3), 363-375

Banks, J., Disney, R., Duncan, A. \& Reenen, J.V. (2004). The internalisation of Public Welfare Policy. CEP Discussion Paper No. 656.

Bengtsson, M., de la Porte, C., \& Jacobsson, K. (2017). Labour market policy under conditions of permanent austerity: Any sign of social investment? Social Policy \& Administration, 51(2), 367-388

Beveridge, W. H. (1942). Social Insurance and Allied services. Presented to Parliament as Command Paper 6404. Report by Sir William Beveridge (The Beveridge Report) London: HMSO.

Beveridge, W. H. (1944). Full Employment in a Free Society. London: Report Allen \& Unwin
Blyth, Mark (2011). Ideas, Uncertainty, and Evolution. In D. Béland \& Robert Henry Cox (Ed.) Ideas and Politics in Social Science Research. Oxford and New York, Oxford University Press. pp. 83-101.

Bonoli, G. (2005). The politics of the new social policies. Providing coverage against new social risks in mature welfare states. Policy and Politics, 33(3), 431-449 DOI: 10.1332/0305573054325765

Bonoli, G. (2011). Active Labour Market Policy in Changing Economic Context. In J. Clasen \& D. Clegg (Ed.) Regulating the Risk of Unemployment. Oxford: Oxford University Press. 318-332

Bonoli, G. \& Palier, B. (2007). When past Reforms Open New Opportunities: Comparing Old Age Insurance Reforms in Bismarckian Welfare Systems. Social Policy and Administration, 41. 555-573 DOI:10.1111/j.1467-9515.2007.00572.x 
Bothfeld, S., Sesselmeier, W. \& Bogedan, C. (Ed.) (2009). Arbeitsmarktpolitik in der sozialen Marktwirtschaft. Vom Arbeitsförderungsgesetz zum Sozialgesetzbuch II und III, Wiesbaden.

Butterwegge, Ch. (2007). Rechtfertigung, Massnahmen und Folgen einer neoliberalen Sozial-Politik. In

Butterwegge, Ch., Lösch, B. \& Ptak, R. (Ed.) Kritik des Neoliberalismus VS Verlag Für Sozialwissenschaften. pp. 123-201.

Butterwegge, Ch. (2014). Krise und Zukunft des Sozialstaates. 5., aktualisiert Auflage. Wiesbaden: Springer VS.

Butterwegge, Ch. (2015). Hartz IV und die Folgen Auf dem Weg in eine andere Republik? Weinheim und Basel: Belitz Juventa.

Cantillon, B. (2011). The paradox of the social investment state: growth, employment and poverty in the Lisbon era. Journal of European Social Policy, 21(5), 432-449

Card, D., Kluve, J. \& Weber, A. (2017). What Works? A MetaAnalysis of Recent Active Labor Market Program Evaluations. Journal of the European Economic Association, 16(3), 894- 931

Carstensen, M.B. (2011). Paradigm Man vs. the Bricoleur: Bricolage as an Alternative Vision of Agency in Ideational Change. European Political Science Review, 3(1), 147-167

Dingeldey, I. (2011). Der Aktivierende Wohlfahrtsstaat. Frankfurt/New York: Campus Verlag

Dörre, K., Scherschel, K. \& Booth, M. (2014). Bewärungsproben für die Unterschicht? Soziale Folgen aktivierende Arbeitsmarktpolitik. Frankfurt am Main: Campus.

Esping-Andersen, G. (1990). The three worlds of welfare capitalism. Princeton, New Jersey: Princeton University Press.

Esping-Andersen, G. (2002) (Ed.) Why we Need a New Welfare State? Oxford: Oxford University Press

EC (1993). Growth, Employment and Competitiveness: The Challenges and Ways Forward into the 21 Century

$\operatorname{COM}(93)$ 700. final, Brussels

EC (2013). Towards Social Investment for Growth and Cohesion - including implementing the European Social Fund 2014-2020 COM (2013) 83 final, Brussels, 20.02.2013 http://eur-lex.europa.eu/legal-content/EN/TXT/ PDF/?uri=CELEX:52013DCo083\&from=EN

Ferrera, M., Hemerijck, A. \& Rhodes, M. (2000). Recasting European Welfare States for the 21st Century.

European Review, 8(3)/July, 427-446 https://doi.org/10.1017/ $\mathrm{S}_{1062798700004981}$
Ferrera, M. (2009). From the Welfare State to the Social Investment State. Revista Internationale di Scienze Social, 117(3), 513-28.

Geissler, R. (2006). Der sozialstruktur Deutschland. Zur gesellschaftlichen Entwicklung mit einer Bilanz zur Vereinigung, Wiesbaden: VS Verlag für Sozialwissenschaften

Giddens, A. (1998). The Third Way: The Renewal of Social Democracy. Cambridge: Polity

Giddens, A. (2001). (Ed.) The Global Third Way Debate. Cambridge: Polity Giesecke, J. (2006). Arbeitsmarktflexibilisierung und soziale Ungleichheit. Wiesbaden: VS Verlag für Sozialwissenschaften

Gilbert, N. \& Gilbert, B. (1989). The Enabling State: Modern Welfare Capitalism in Amerika. New York: Oxford University Press

Hall, P. (1993). Policy paradigms, social learning, and the state: e case of economic policymaking in Britain. Comparative Politics, 25(3), 275-296

Hayek, F. (1991 [1944]). Road to the Serfdom, UK: Routledge Press Hemerijck, A. (2013). Changing Welfare States. Oxford: Oxford University Press

Hemerijck, A. (2015). The Quiet Paradigm Revolution of Social Investment. Social Politics, 22(2), 242-256

https://doi.org/10.1093/sp/jxvoog

Hemerijck, A. (2017). (Ed.) The Uses of Social Investment. Oxford: Oxford University Press

Hemerijck, A. \& Berghman, J. (2004). The European Social Patrimony- Depending Social Europe through Legitimate Diversity. In T.Sakellaropoulos. \& J. Berghman (Ed.) Connecting Welfare Diversity within the European Social Model. Antwerp -Oxford- New York: Intersentia. pp. 9-55

Knotz, C. (2018). A rising workfare state? Unemployment benefit conditionality in 21 OECD countries, 1980-2012. Journal of International and Comparative Social Policy, 34(2). 91- 108 DOI:10.1080/21699763.20 18.1472136

Knuth, M. (2005) Reflexionen zum deutschen Reformpfad von dem Hintergrund der Erfahrung westeuropäischer Nachbarn. In Burghard, $\mathrm{H}$. - Enggruber, R. (szerk.) Soziale Dienstleistungen am Arbeitsmarkt: soziale Arbeit zwischen Arbeitsmarkt- und Sozialpolitik. Winheim: Beltz Juventa, pp. $175-192$

Lodemel, I. \& Trickey, H. (2000). 'An offer you can't refuse' Bristol: The Policy Press

Lutz, G. (1984). Der kurze Traum immerwährender Prosperität. Frankfurt am Main: Campus Verlag 
Mailand, M. \& Arnholtz, J. (2015). Formulating European work and employment regulation during the pre-crisis years: Coalition building and industrial inertia. Journal of European Social Policy, 25(2),194-209 doi:10.1177/0958928715573482

Marshall, T. H. (1950). Citizenship and Social Class: And Other Essays. Cambridge: University Press

Morel, N., Palier, B. \& Palme, J.(Ed.) (2012) Towards a Social Investment Welfare State. Ideas, Policies and Challenges. Bristol: Policy Press

Moyson, S., Scholten, P. \& Weible, C.M. (2017). Policy learning and policy change: theorizing their relations from different perspectives, Policy and Society, 36(2). 161-177 DOI:10.1080/14494035.2017.1331879

Nolan, B. (2013). What use is „social investment'? Journal of European Social Policy, 23(5), 459-468 DOI: 10.1177/0958928713499177

OECD (1994). The OECD Jobs Study. Facts, Analysis, Strategies. Paris: OECD. https://www.oecd.org/els/emp/1941679.pdf [03.02.2019.]

OECD (1997a). The OECD Job Strategy: Making Work Pay: Taxation, Benefits, Employment and Unemployment. Paris: OECD.

OECD (1997b). Beyond 2000: The New Social Policy Agenda. Paris: OECD Offe, C (1984). Contradictions of the Welfare State. London: Hutchinson Co. (Publishers) Ltd.

Offe, C. (2003). Freiheit, Sicherheit, Effizienz. Spannungen zwischen Gerechtigkeitsnormen für die

Arbeitsmarkt und Wohlfahstsstaat. In J. Allmendinger (Ed..) Entstaatlichung und soziale Sicherheit. Verhandlungen des 31 . Kongresses der Deutschen Gesellschaft für Soziologie in Leipzig 2002. Opladen: VS Verlag für Sozialwissenschaften

Palier, B. (Ed.) (2010). A Long Goodby to Bismarck? The Politics of Welfare Reform in Continental Europe. Amsterdam: University Press

Pierson, P. (1998). Irresistible Forces, Immovable Objects: Post-industrial Welfare States confront Permanent Austerity. Journal of European Public Policy. 5(4), 539-56o http://dx.doi.org/10.1080/13501769880000011

Pierson, P. (2001). 'Coping with Permanent Austerity: Welfare state Restructuring in Affluent Democracies' In P. Pierson (Ed.) The new politics of the welfare state. Oxford: Oxford University Press

Rueda, D. (2007). Social democracy inside out. Partisanship and labor market policy in industralised democracies. Oxford: Oxford University Press

Schmid, G. - Oschmiansky, F. (2006) Arbeitsmarktpolitik und Arbeitslosenversicherung 1966-1974. In Geschichte der Sozialpolitik in Deutschland seit 1945. Berlin: Bundesministerium für Arbeit und Soziales und Bundesarchiv. Band 5
Sonnenfeld,Ch.(2001). ErzwungeneAngebote:Beschäftigungsförderung zu Niederlöhnen. In Stolz-Willig, B. (Ed.) Arbeit und demokratie, Solidaritätzpotentiziale im Flexibilizierten kapitalismus. Hamburg: VSA Verlag

Torfing, J. (1999). Workfare with welfare: Recent reforms of the Danish welfare state.

Journal of European Social Policy. 9(1), 5-28

Trube, A. (2003). Aktivierende Sozoalstaat- pogrammatik, praxis und Probleme. Die Neue gesellschaft Frankfurter Hefte 8. 336

Wiesenthal, H (2006) Geselsschafts-steverung und gesellschaftliche Selbssteuerung. Wiesbaden: VS Verlag

Zito, A., \& Schout, A. (2009). Learning theory reconsidered: EU integration theories and learning. Journal of European Public Policy, $16(8), 1103-1123$ 